\title{
THROMBOCYTOPENIA IN CONGENITAL HEART DISEASE
}

\author{
BY \\ D. VEREL, S. J. MAZURKIE, E. K. BLACKBURN, J. L. EMERY, \\ S. VARADI, AND L. WOLMAN \\ From the Departments of Cardiology, Pathology and Neurosurgery, The United Sheffield Hospitals
and City General Hospital, Sheffield \\ Received June 21, 1961
}

It is well known that idiopathic thrombocytopenic purpura occurs most commonly during childhood but its incidence is difficult to estimate. MacFarlane (1960) found that in 737 cases 45 per cent were aged 15 years and younger, while Wintrobe (1956) noted that in childhood purpura was most frequent between the ages of two and eight years. The disease is uncommon in the general population. The present communication describes five children who were found to have thrombocytopenic purpura. Four of these appeared in a group of 100 patients with cyanotic congenital heart disease, while one was found in a much larger group of patients with acyanotic congenital heart disease.

\section{CASE REPORTS}

Case 1. A girl of 19 had been cyanosed from birth as a result of Fallot's tetralogy. At the age of eight years the Blalock-Taussig operation was performed with considerable improvement. When she was 13 years old she developed an acute illness with icterus, transient neurological manifestations, anæmia and thrombocytopenic purpura. Investigations at this time showed hæmoglobin $5.5 \mathrm{~g}$.; white cells $5,900 / \mathrm{cu} . \mathrm{mm}$.; platelets 19,000/cu. mm.; bleeding time (Duke) was $6 \mathrm{~min}$. and $13 \mathrm{~min}$.

Bone marrow. Examination showed medium cellularity with some areas of increased erythropoiesis, and with slight deficiency in granulocytes and megakaryocytes. Lymphocytes in a peripheral smear were consistent with glandular fever.

The episode was thought to be thrombotic thrombocytopenic purpura.

The patient recovered and had no further purpura until the age of $18 \frac{1}{2}$ years when she began to deteriorate with increasing cyanosis. The most recent blood examination showed: hæmoglobin $20.4 \mathrm{~g} . / 100 \mathrm{ml}$.; white cells $6,900 / \mathrm{cu}$. mm.; platelets $46,000 / \mathrm{cu}$. mm. The sternal marrow was found to be very active; there was normoblastic erythropoiesis with megakaryocytes normal or slightly increased. The patient received no medication other than folic acid and penicillin during the acute illness.

Case 2. A boy of 10 had been cyanotic and dyspnœic from birth with a history of squatting. Angiocardiography at the age of five years showed transposition of the great vessels. At the age of three years he developed crops of petechiæ. Blood count showed: hæmoglobin $19.9 \mathrm{~g} . / 100 \mathrm{ml}$; white blood count 7,600/cu. mm.; platelets 14,000/cu. mm.; bleeding time (Duke) 2 min. 15 seconds; clotting time (Dale and Laidlaw) 7 min. 30 seconds.

Bone marrow: normal erythropoiesis. Megakaryocytes were slightly increased in numbers with platelet formation a little reduced. Differential white cell count normal. He was given a six weeks course of cortisone. Platelet counts fluctuated, reaching the level of 70,000 and was $23,000 / \mathrm{cu}$. $\mathrm{mm}$. at the time of discharge. The low platelet counts have persisted for seven years and he has continued to have crops of petechiæ and has once had hæmaturia.

Case 3. A boy of 9 had been cyanosed from birth and dyspnoa became prominent as he became more active. An angiocardiogram at the age of five years showed transposition of the great vessels.

Lanoxin elixir $0.025 \mathrm{mgms}$. thrice daily was given at the age of six years. He did fairly well despite considerable cyanosis and stunting till the age of nine years when vomiting and pain in the back of the head came 
on suddenly. There were purpuric spots on the elbows, knees and thighs. Straight leg raising produced pain on both sides. The blood contained 30,000 platelets/cu. $\mathrm{mm}$.

The bone marrow: showed maturation arrest of the megakaryocytes. He was treated with ACTH with no effect upon his platelet count. On the twelfth day he suddenly collapsed and died.

Necropsy showed massive pulmonary collapse on the left side due to a large hæmothorax. The brain was extremely swollen with congestion of all pial vessels and blood in the subarachnoid space. The heart showed transposition of the great vessels with atrial and ventricular septal defects.

Case 4. A full-term baby with cyanosis noted at birth was seen at the age of six weeks. Soon after birth a purple area had appeared over the midline of the scalp and later a similar lesion appeared in the right axilla. Blood count showed: hæmoglobin $17.7 \mathrm{~g}$./100 ml.; white cells 13,800/cu mm.; platelets 5,000/cu. mm.; bleeding time (Duke) 3 min. 15 seconds. The child died suddenly at the age of six weeks.

Necropsy: heart showed a persistent truncus arteriosus with ventricular septal defect. The lungs and liver were slightly congested. Nothing abnormal was found in the brain. There was a congenital defect in the midline of the scalp with a good deal of hæmorrhage and small vessel thrombosis.

The bone marrow was very cellular. Megakaryocytes were decreased in number and appeared small and shrunken.

Case 5. A boy, aged 16, was found to have a heart murmur on routine examination at the age of two years. He was well and had no cardio-respiratory symptoms. At the age of 11 years he had rheumatic fever, and a year later he showed easy bruising. Epistaxis developed and thrombocytopenia was noted. About the same time, at the age of 15 years, he was admitted for cardiac investigation. The blood count showed: hæmoglobin 15.0 g. $/ 100 \mathrm{ml}$.; white cells $9,100 / \mathrm{cu}$. mm.; platelets $10,000 / \mathrm{cu}$. $\mathrm{mm}$. The bone marrow showed plentiful megakaryocytes with some cells actively dividing.

Cardiac catheterization showed mild infundibular pulmonary stenosis. The right ventricular pressure was $35 / 0 \mathrm{~mm}$. Hg. Pressure at the infundibulum was $22 / 0$. The pulmonary arterial pressure measured $20 / 10 \mathrm{~mm}$. Hg. A splenectomy was performed and at the time of discharge the platelet count was $300,000 / \mathrm{cu} . \mathrm{mm}$.

\section{DisCUSSION}

Emery et al. (1957) described two cases of fatal hæmorrhagic thrombocytopenia in infants. In both of these children the radii were absent. They quoted five other recorded patients with associated defects. Congenital cardiac abnormalities were noted in three of these. No child in this series survived longer than $6 \frac{1}{2}$ months. In all cases megakaryocytes were scanty or absent in the marrow. Symptoms were noted in the first week of life in six cases, and after six weeks in one patient. Noonan et al. (1960) reported scanty platelets in the peripheral blood of seven of 50 cases of transposition of the great vessels and a count of 31,000 per cu. $\mathrm{mm}$. in an eighth. In one of these patients marrow examination showed hypocellularity.

The occurrence of four cases of thrombocytopenic purpura from among 100 patients with cyanotic congenital heart disease in the present series gives an incidence of 4 per cent which is much higher than would be expected among patients even in this age group. Two occurred in a group of 17 transpositions ( 11.8 per cent) which approaches the 16 per cent incidence of low platelet counts found by Noonan et al. The high incidence in transposition may indicate a relation to severe cyanosis. All four cases reported here were deeply cyanosed at rest. Three of this group of four had a slight decrease in total numbers of megakaryocytes in bone marrow smears, while one (Case 2) had a slight increase. All four showed a reduction in platelet formation with two (Cases 3 and 4) showing maturation arrest.

The bone marrow findings of Case 5 were those one would expect in idiopathic purpura, i.e. adequate or increased megakaryocytes with active platelet production. These findings in the single case with acyanotic congenital heart disease would suggest that this is merely a coincidental finding of two unrelated pathological conditions in one patient. Splenectomy has not been performed on any of the cases in the cyanotic group and its effect can, therefore, not be evaluated.

The importance of thrombocytopenia with or without purpura in cyanotic congenital heart disease is evident as it must constitute a grave surgical hazard. The occurrence of spontaneous subarachnoid hæmorrhage in Case 3 suggests a possible partial explanation for the previously noted high 
incidence of cerebrovascular accidents and neurological complications in congenital heart disease. Tyler and Clark (1957a) recorded an incidence of loss of consciousness or convulsions in 14.7 per cent to 24.2 per cent of patients with cyanotic congenital heart disease as opposed to 3.6 per cent with other forms. They also noted (1957b) that the highest incidence of cerebrovascular accidents occurred in the groups of patients with the more severe forms of congenital heart disease such as transposition of the great vessels where the incidence was 11 per cent. Of 14 coming to necropsy all showed large infarctions in the distribution of the middle cerebral artery. Moreover, two other patients had hemiplegia, one with a subdural hæmatoma and the other with a chronic epidural hæmatoma. Both had a history of injury and it is conceivable that thrombocytopenia could have been a contributing factor. In reviewing 109 patients with a history of convulsions the same authors (Tyler and Clark, 1957c) found the majority of these to be due to cyanotic attacks, cerebral abscess and cerebral thrombosis. However, in 10 patients of their group the cause was listed as "idiopathic" and here again it is possible that thrombocytopenia was a factor.

\section{SUMMARY}

Idiopathic thrombocytopenic purpura was found in four per cent of a group of patients with cyanotic congenital heart disease and in one uncyanosed patient. The importance of this finding in relation to cardiac surgery and the risk of cerebral vascular accidents is emphasized.

\section{REFERENCES}

Emery, J. L., Gordon, R. R., Rendle-Short, J. T., Varadi, S. and Warrack, A. J. N. (1957). Blood, $12,567$. MacFarlane, R. E. (1960). Quart. J. Med., 10, 1.

Noonan, J. A., Nadas, A. S., Rudolph, A. M. and Harris, G. B. C., (1960). N. Eng. J. Med., $263,684$.

Tyler, R. H., Clark, D. B., (1957a). Arch. Neurol. Psychiat., 77, 17.

- - (1957b). Arch Neurol. Psychiat., 77, 483.

-_- (1957c). Arch. Neurol. Psychiat., 79, 506.

Wintrobe, M. M. (1956). Clinical Hamatology. 4th edn., Lea and Febiger, Philadelphia.

\section{ADDENDUM}

Since this paper was prepared a further case has been seen. A child of four days was admitted in cardiac failure with gross cyanosis. Cardiac catheterization was incomplete but revealed a right atrial pressure of $12-14 \mathrm{~mm}$. $\mathrm{Hg}$ with evidence of an atrial septal defect. The platelet count was 70,000 per cu. mm. Necropsy showed tricuspip atresia, atrial septal defect, ventricular septal defect, patent ductus arteriosus, stenosis of the aortic arch and transposition of the great vessels. 